Institute of $\mathbf{F}_{\text {ood and }} \mathbf{A}_{\text {gricultural }} \mathbf{S}_{\text {ciences }}$

\title{
2003 Handbook of Employment Regulations Affecting Florida Farm Employers and Workers: Social Security and Medicare [Federal] ${ }^{1}$
}

Leo C. Polopolus, Michael T. Olexa, Fritz Roka, and Carol Fountain ${ }^{2}$

\section{Purpose}

To provide social benefits to qualified workers who retire, become disabled, and/or require medical assistance.

\section{Who Must Comply}

Farm employers must make Social Security and Medicare deductions:

- If they pay an employee $\$ 150$ or more in cash wages during a calendar year.

- If they pay total wages of $\$ 2,500$ or more per year to all employees. (These criteria are identical to those for income tax withholding).
- For most types of agricultural labor (including the employer's parents, spouse, and children eighteen years of age and older).

- For holders of unexpired I-688A and I-688 employment authorization cards and I-151 permanent resident cards because they are considered residents for purposes of Social Security and Medicare. Employers must deduct Social Security and Medicare taxes from their wages.

- In the case of H-2A temporary foreign agricultural workers, they are not covered by the program. Thus, employers certified by the Department of Labor to employ H-2A workers do not have to withhold Social Security and Medicare taxes from H2-A worker earnings.

1. This is EDIS document FE415, a publication of the Department of Food and Resource Economics, Florida Cooperative Extension Service, Institute of Food and Agricultural Sciences, University of Florida, Gainesville, FL. Published July 2003. This information is included in Circular 1200, Handbook of Employment Regulations Affecting Florida Farm Employers and Workers. First published February 1992 as Circular 1043 . Revised December 2002 as Circular 1200. Please visit the EDIS website at http://edis.ifas.ufl.edu.

2. Leo C. Polopolus, Professor Emeritus, Department of Food and Resource Economics, University of Florida, Gainesville, FL; Michael T. Olexa, Professor, Department of Food and Resource Economics, University of Florida, Gainesville, FL; Fritz Roka, Associate Professor, Department of Food and Resource Economics, Southwest Florida Research and Education Center, Immokalee, FL; and Carol Fountain, Assistant Editor, Department of Food and Resource Economics, University of Florida, Gainesville, FL; Florida Cooperative Extension Service, Institute of Food and Agricultural Sciences, University of Florida, Gainesville, FL.

This document is designed to provide accurate, current, and authoritative information on the subject. However, since the laws, administrative rulings, and court decisions on which it is based are subject to constant revision, portions of this publication could become outdated at any time. This publication is distributed with the understanding that the authors are not engaged in rendering legal or other professional advice, and the information contained herein should not be regarded as a substitute for professional advice. For these reasons, the utilization of these materials by any person constitutes an agreement to hold harmless the authors, the Institute of Food and Agricultural Sciences, and the University of Florida for any liability claims, damages, or expenses that may be incurred by any person as a result of reference to or reliance on the information contained in this publication.

The Institute of Food and Agricultural Sciences is an equal opportunity/affirmative action employer authorized to provide research, educational information and other services only to individuals and institutions that function without regard to race, color, sex, age, handicap, or national origin. For information on obtaining other extension publications, contact your county Cooperative Extension Service office. Florida Cooperative Extension Service/Institute of Food and Agricultural Sciences/University of Florida/Christine Taylor Waddill, Dean. 
- In the case of farm labor contractors, farmers can rely on them to withhold and deposit Social Security and Medicare taxes as part of the farm labor contractors' services. IRS uses a twenty-factor test to determine who is responsible for these taxes.

- It is mandatory for farm operators to keep a record of the farm labor contractor's name, permanent address, and employer identification number.

\section{Exceptions}

Some types of family employment are not covered by Social Security and Medicare. This exemption is not optional. Noncovered family employment is any work performed by:

- A child under eighteen years of age in the employ of his or her father or mother.

- A parent in the employ of a son or daughter performing domestic service in or about the home of the son or daughter or work not in the course of the son's or daughter's trade or business.

- The family exclusion does not apply when the employer is a corporation or association classified as a corporation or a partnership, unless the family relationship exists between the employee and all the partners.

- H-2A temporary foreign agricultural workers are exempt from this program, as noted above.

\section{Employers Must}

- Social Security Taxes. Withhold 6.2 percent of the employee's cash wages (including the initial \$150) and add 6.2 percent as the employer's contribution (during 1997 the tax is limited to the first $\$ 65,400$ of annual wages).

- Medicare Taxes. Withhold 1.45 percent of the employee's cash wages (including the initial \$150) and add 1.45 percent as the employer's contribution. The taxable wage base for Medicare is unlimited. The total annual combined employer-employee taxes for Social
Security and Medicare are 15.3 percent of gross wages.

\section{Deposit / Record-Keeping Rules}

Employers must deposit FICA taxes in a Federal Reserve Bank or authorized financial institution, depending on the size of the combined deductions/contributions. Deposits must be accompanied by Form 8109, "Federal Tax Deposit Coupon." The deposit rule schedule is the same as for income tax withholding.

Employees must be given a Form W-2, "Wage and Tax Statement," showing the amount of earnings, income tax withheld, and amount of Social Security and Medicare deductions by January 31 st of each year. Those employees who had zero withheld must be provided with Notice 797, "The Earned Income Tax Credit Refund," or "Copy C" of the W-2 Form. Employees who claimed total exemption in the previous year must fill out a new W-4 Form by February 15 th of the following year.

- Employers must deposit FICA taxes in a Federal Reserve Bank or authorized financial institution, depending on the size of the combined deductions/contributions. Deposits must be accompanied by Form 8109, "Federal Tax Deposit Coupon." The deposit rule schedule is the same as for income tax withholding.

- Employees must be given a Form W-2, "Wage and Tax Statement," showing the amount of earnings, income tax withheld, and amount of Social Security and Medicare deductions by January 31 st of each year. Those employees who had zero withheld must be provided with Notice 797, "The Earned Income Tax Credit Refund," or "Copy C" of the W-2 Form. Employees who claimed total exemption in the previous year must fill out a new W-4 Form by February 15th of the following year.

- Attach copies of each employee's W-2 Form to Form W-3, "Transmittal of Income and Tax Statements," and send both to the Social Security Administration by February 28th. File Form 943, "Employer's Annual Tax Return for Agricultural Employers," with the IRS by January 31st of 
each year (or February 10th if taxes were paid in full).

- The total of W-2 wages and taxes should equal total of the W-3 wages and taxes, which should equal the total of Form 943 wages and taxes. That figure should then equal the total of taxes deposited. Reconciling and correcting any differences between the various forms will reduce the chance of notices, penalties, and audits.

- Employers are also required to keep payroll records for four years after the taxes are due and paid. These records must include:

- Names, addresses, and occupations of employees.

- Periods of employment.

- Social Security numbers.

- Employer's identification number (EIN).

- Total amount and date of each wage payment.

- Amounts deducted for FICA and income tax withholding.

\section{Self-Employed Farmers}

Under the Self-Employed Contributions Act, self-employed farmers (unincorporated) who report a net income of $\$ 400$ or more from farming operations must contribute to Social Security and Medicare. The contribution rate in 1997 was 12.4 percent of annual net earnings up to $\$ 65,400$ for Social Security and 2.9 percent of annual net earnings (unlimited) for Medicare (15.3 percent total).

If a farmer also earns wages subject to Social Security and Medicare deductions, he or she must contribute to the self-employment income until the combined earnings reach the 1997 Social Security limit of $\$ 65,400$ and the 1997 unlimited Medicare. Self-employed income is reported on Schedule F.

\section{Additional Information}

- Circular A, Agricultural Employer's Tax Guide, Publication 51, Department of Treasury, Internal Revenue Service. (Published annually.)

- Farmer's Tax Guide, Publication 225, Department of the Treasury, Internal Revenue Service. (Published annually.)

The following fact sheets are available from most local Social Security offices

- No. 4 - If You're Self-Employed.

- No. 5 - Reporting Farm Income.

- No. 6 - Crew Leaders and Farmers.

- No. 8 - Agricultural Workers.

\section{Responsible Agency}

- U.S. Department of Health and Human Services

- Social Security Administration

For local Social Security offices, see telephone directory for

- U.S. Government

- Health and Human Services

- Social Security Administration

Dial toll-free 1(800) 772-1213

For local Internal Revenue Service offices, see telephone directory for

- U.S. Government

- Internal Revenue Service

For ordering tax forms, dial toll-free 1(800) 829-3676

For tax information and assistance, dial toll-free 1(800) 829-1040 